DEAR SIR

\section{Inaccurate quotation}

I have received a copy of The Complex Secret of Brief Psychotherapy by Professor James Gustafson, just published by Norton, New York. During its preparation the draft was sent to me chapter by chapter by the author, a personal friend, and we corresponded about the ideas it contains. Though the cover of the book carries a prepublication tribute by me as well as others, this was based on the draft and I had not before seen a copy of the finished book or been shown the 'Notes to Chapters'. Unfortunately, due to a misunderstanding by the author of remarks in one of my letters, Note 13 on page 413 contains a comment about D. W. Winnicott, whose work is the subject of the chapter concerned, which states: 'Robin Skynner suggests to me that it is even better if the therapist has been ill before with the difficulty the patient is having, but has "tunnelled his own way out" (personal communication). Skynner knew Winnicott well and suggests that his enormous capacity as a therapist came from his being so at ease with the patient's being ill. Winnicott had been quite ill himself, but had somehow managed to become well-hence his accessibility, his ease with disturbance.'

While it is my experience and belief that therapists of Winnicott's stature have often developed their skills in the course of mastering the kind of early family difficulties that in other circumstances might have led to mental disorder, I did not in fact know Winnicott well, have no knowledge of his personal life, and have no reason to believe that he ever suffered a clinical emotional 'illness' of any kind.

I have requested the publisher to revise this not in further reprints of the book, and am most grateful to the Bulletin for allowing space for this correction before the book begins to circulate widely among colleagues.

A. C. ROBIN SKYNNER

43 Meadway

London NWII 7AY

\section{Defence associations}

Dear Sirs

I have recently been forced to cancel my subscription to the Royal College of Psychiatrists. This decision has been forced upon me by the recent large increase in Medical Defence Union subscription. It is one I deeply regret as I value membership of the Royal College of Psychiatrists, especially as a continuing source of education. I am currently employed as a clinical assistant earning $£ 8,650$ working full sessions. I have family commitments and would ultimately like to be a 'sub-consultant'.

If the Medical Defence Union does not introduce a salary-related subscription beyond the current half price subscription for annual income of less than £5,500 I may ultimately be forced to discontinue medical practice. I am aware of several colleagues in the same position as myself.

44 Priory Avenue SAlly A. Wilkinson

Westbury on Trym, Bristol
DeAR SIRS

Others like myself must find it irksome that subscriptions to existing Defence Associations increase remorselessly because we are made to pay for the negligences of our surgical colleagues. It is not good for them to be sheltered from the bad effects of their activities, however few these may be, and it cannot be good for patients either.

It is surely time for the College to institute a Psychiatric Defence Union or Protection Society. With a potential membership of some thousands and a subscription of $£ 100$ a large income would accrue, while outgoings apart from administrative costs and modest re-insurance would be limited to small settlements on rare occasions. Financially it cannot fail.

Whiston Hospital

Prescot, Merseyside

\section{DEAR SIRS \\ Suspension of consultants}

The occurrence of unjust and unwarranted suspension of consultants up and down the country with its accompaniment of unjustly smeared lives and reputations has gone on for too long. The present state of affairs where one bureaucrat, or group of doctors acting through him, can harass individuals unfairly, is corrupting to the fabric of the NHS and to the honest consideration of ideas that are not stereotyped and part of the establishment. The process had been particularly rampant in psychiatry.

It is now time to collate and examine what has been going on. I would be grateful if any consultant (or other doctor) who has had this harassment would kindly send me details so that the situation can be systematically looked at in the interest of a cleaner NHS.

HARRY JACOBS Chairman, Society of Clinical Psychiatrists

\section{Severalls Hospital \\ Boxied Road \\ Colchester, Essex}

\section{Employment rehabilitation of the mentally ill}

DeAr Sirs

We are carrying out a study of employment rehabilitation of the mentally ill for the Manpower Services Commission. We are particularly interested in new approaches in this field and we would be grateful if anyone with a special responsibility for preparing psychiatric patients for their return to work who would like to exchange views, would write to us.

Division of Psychiatry

MAURICE LIPSEDGE

Guy's Hospital

London Bridge, SEI 9RT

Department of Psychology

ANGela B. SUMMERFIELD

University of London 